\title{
ENTREPRENEURSHIP AND BRAIN DRAIN MUTUAL EFFECT IN THE CASE OF THE REPUBLIC OF N. MACEDONIA
}

\author{
Hristina SERFIMOVSKA ${ }^{1}$, Marija APOSTOLOVA NIKOLOVSKA ${ }^{2 *}$ \\ 1University Goce Delcev, Krste Misirkov 10-A, 2000 Shtip, Republic of N. Macedonia \\ ${ }^{2}$ Government of the Republic of N. Macedonia, bul. Ilinden 2, 1000 Skopje, Republic of N. \\ Macedonia \\ *Correspondence: marija.apostolova@primeminister.gov.mk
}

\begin{abstract}
The purpose of this research is to gain knowledge about the relation of the entrepreneurship and its impact on phenomenon of the brain drain in order to help government policy makers to successfully deal with this problem. The importance of the issue of brain drain for $\mathrm{N}$. Macedonia is shown by other data from the relevant statistical reports presented in the paper. This paper studies the "brain drain" phenomenon through the prism of the influential factors such an employment immediately after graduation, party employment, the disproportion of staff with the demand on the labor market, discrimination on various grounds in employment, unstable jobs and a salary that does not correspond to the competencies of the employee, the low level of protection and guarantee of workers' rights, especially when it comes to young people, further education and retraining, deep politicization etc. These factors were part of the research conducted in Republic of N. Macedonia among persons over 18 years of age.
\end{abstract}

KEYWORDS: brain drain, entrepreneurship, intellectual capital JEL CLASSIFICATION: L26; I25

\section{INTRODUCTION}

Brain Drain is one of the prevalent migration issues in the South East Europe region (SEE). Even though the SEE region has traditionally experienced significant emigration movements, the latest trends in the region are undoubtedly worrying. In 2020, the World Economic Forum released the Global Competitiveness report, indicating that four Balkan countries are among countries with the biggest brain-drain 
in the world. Young people are the most represented group among emigrants, paving even more challenges for the future development of these countries. Unemployment, low wages, corruption and lack of opportunities have been driving an increasing number of young people from the Balkans to Western Europe, the US and Gulf countries. Youth unemployment rates in the region are among the highest in the world. Youth unemployment in the Western Balkans continued its downward trend, but despite declining the situation of the young in the labor market remains alarming. Study on Youth Employment in the Western Balkan show that he highest youth unemployment rates are found in Kosovo*, North Macedonia and Bosnia and Herzegovina, and (now) Montenegro, each being in excess of 30\% in 2020 despite declining in recent years; in Kosovo* the youth unemployment rate peaked at $55.4 \%$ in 2018, while the lowest youth unemployment rate was 24.3\% in Montenegro in 2019 (Ramhorst,2021). The study notes that for example, in Serbia the youth unemployment rate is about 2.8 times that of the overall unemployment rate, while in Kosovo* it is 1.4 times (Ramhorst,2021). At the same time it is pointed that the unemployment rate gap is around 2.3, similar to the EU-27 (Ramhorst,2021).

\section{BRAIN DRAIN AS A GLOBAL ISSUE - capacity of countries to retain talented people}

Bosnia and Herzegovina (BiH), Croatia, N. Macedonia, and Serbia are among the top-ranked countries with the biggest brain-drain in the world, according to the Global Competitiveness Report released by the World Economic Forum. On the scale of 1 to 7 $(1=$ all talented people leaving the country; $7=$ all talented people staying in the country), BiH scored 1.76, followed by Croatia (1.88), N. Macedonia (2.13) and Serbia (2.31). The Global Talent Competitiveness Index (GTCI) is an annual benchmarking report that looks at the patterns of Skilled Worker Migration and determines which countries are succeeding the most in the global competition for talent. The GTCI's 2019 report was published in January 2020. The paper shows the rankings for 2019 and 2018 (Table 1 and Table 2). 
Table 1 - Global Talent Competitiveness Index for countries from Europe

\begin{tabular}{|l|c|c|}
\hline $\begin{array}{l}\text { Country from } \\
\text { Europe }\end{array}$ & $\begin{array}{l}\text { Rank } \\
\text { 2019/125 }\end{array}$ & $\begin{array}{l}\text { Rank } \\
\text { 2018/119 }\end{array}$ \\
\hline Germany & 14 & 19 \\
\hline Sweden & 7 & 5 \\
\hline United Kingdom & 9 & 8 \\
\hline Denmark & 5 & 7 \\
\hline Finland & 6 & 6 \\
\hline France & 21 & 21 \\
\hline Norway & 4 & 4 \\
\hline Luxembourg & 10 & 10 \\
\hline Austria & 18 & 18 \\
\hline Belgium & 17 & 16 \\
\hline
\end{tabular}

Source: INSEAD, (2020). The Global Talent Competitiveness Index 2020: Global Talent in the Age of Artificial Intelligence, Fontainebleau, France., INSEAD, (2019). The Global Talent Competitiveness Index 2019: Global Talent in the Age of Artificial Intelligence, Fontainebleau, France.

Table 2 - Global Talent Competitiveness Index for SEE region

\begin{tabular}{|l|c|c|}
\hline SEE region & $\begin{array}{c}\text { Rank } \\
2019 / 125\end{array}$ & $\begin{array}{c}\text { Rank } \\
2018 / 119\end{array}$ \\
\hline Slovenia & 29 & 28 \\
\hline Bulgaria & 54 & 47 \\
\hline Greece & 44 & 42 \\
\hline Croatia & 55 & 48 \\
\hline Serbia & 68 & 69 \\
\hline Montenegro & 51 & 58 \\
\hline Albania & 75 & 78 \\
\hline N. Macedonia & $/ 1$ & 59 \\
\hline Bosnia and Herzegovina & 86 & 89 \\
\hline
\end{tabular}

Source: INSEAD, (2020). The Global Talent Competitiveness Index 2020: Global Talent in the Age of Artificial Intelligence, Fontainebleau, France., INSEAD, (2019). The Global Talent Competitiveness Index 2019: Global Talent in the Age of Artificial Intelligence, Fontainebleau, France.

The Global Competitiveness Index is an indicator for the capacity of each country to retain talent. Results in 2019 show that most of the SEE countries are facing a high youth unemployment that drives emigration from the SEE region. The ranking shows that in particularly young and talented people from SEE are deserting their home countries, seeking professional development and recognition of their talent. Covering 141 economies, the Global Competitiveness Index for 2019 measures national competitiveness - defined as the set of institutions, policies and factors that

\footnotetext{
${ }^{1}$ For lower positions in the GTCI ranking, one should take into account the two countries (the Plurinational State of Bolivia and the Former Yugoslav Republic of Macedonia) that have dropped out of the GTCI this year because of a lack of available data as well as the eight countries that are new additions to the index.
} 
determine the level of productivity. The paper presents the rankings from the Global Competitiveness Index for the last four years (Table 3 and Table 4).

Table 3 - Country rating by capacity rating talent in SEE region (ranking from Global Competitiveness Index)

\begin{tabular}{|c|c|c|c|c|}
\hline SEE region & $\begin{array}{l}\text { Rank } \\
2019 / 141\end{array}$ & $\begin{array}{l}\text { Rank } \\
2018 / 140\end{array}$ & $\begin{array}{l}\text { Rank } \\
2017 / 137\end{array}$ & Rank 2016/138 \\
\hline Slovenia & 35 & 35 & 48 & 56 \\
\hline Bulgaria & 49 & 51 & 49 & 50 \\
\hline Greece & 59 & 57 & 87 & 86 \\
\hline Croatia & 63 & 68 & 74 & 74 \\
\hline Serbia & 72 & 65 & 78 & 90 \\
\hline Montenegro & 73 & 71 & 77 & 82 \\
\hline Albania & 81 & 76 & 75 & 80 \\
\hline N. Macedonia & 82 & 84 & $/^{2}$ & 68 \\
\hline $\begin{array}{ll}\text { Bosnia } & \text { and } \\
\text { Herzegovina } & \end{array}$ & 92 & 91 & 103 & 107 \\
\hline
\end{tabular}

Source: Global Competitiveness Index

Table 4 Country rating by capacity rating talent in country from Europe

\begin{tabular}{|l|c|r|r|c|}
\hline $\begin{array}{l}\text { Country from } \\
\text { Europe }\end{array}$ & Rank 2019/141 & Rank 2018/140 & Rank 2017/137 & $\begin{array}{l}\text { Rank } \\
\text { 2016/138 }\end{array}$ \\
\hline Germany & 7 & 3 & 5 & 5 \\
\hline Sweden & 8 & 9 & 7 & 6 \\
\hline UK & 9 & 8 & 8 & 12 \\
\hline Denmark & 10 & 10 & 12 & 10 \\
\hline Finland & 11 & 11 & 10 & 21 \\
\hline France & 15 & 17 & 22 & 11 \\
\hline Norway & 17 & 16 & 11 & 20 \\
\hline Luxembourg & 18 & 19 & 19 & 19 \\
\hline Austria & 21 & 22 & 18 & 17 \\
\hline Belgium & 22 & 21 & 20 & 32 \\
\hline Spain & 23 & 26 & 34 & \\
\hline
\end{tabular}

Source: Global Competitiveness Index

Highly trained and qualified people are emigrating from N. Macedonia. According to the Global Competitiveness Report of the World Economic Forum, N. Macedonia is among the countries with the biggest brain drain. According to Balkan Barometer 2019, the overall hierarchy of the region's problems remains unchanged for the fourth year running: 1) Unemployment, 2) Economic Situation, 3) Corruption, 4) Crime, 5) Brain-Drain/Emigration (Balkan Barometer, 2019). It is not just unemployment and

${ }^{2}$ Klaus, Schwab. (2017). The Global Competitiveness Report 2017-2018. World Economic Forum: Geneva. accessed on 1 december2020.http://www3.weforum.org/docs/GCR2017-

2018/05FullReport/TheGlobalCompetitivenessReport2017\%E2\%80\%932018.pdf. Countries excluded because of insufficient data this year are Barbados, Bolivia, Côte d'Ivoire, Gabon, and FYR Macedonia. 
economic hardships that drive the youth to depart - political and cultural factors play an important role as well.

\section{BRAIN DRAIN IN THE SEE REGION - CURRENT SITUATION}

The emigration rates of high-skilled workers are high, especially in some of the lower-income countries in the Balkans and Eastern Europe. Among people with higher education, 55 percent in Bosnia and Herzegovina; more than 40 percent in Armenia and Latvia; and almost 40 percent in Albania, N. Macedonia, and Romania have emigrated. Various factors drive brain drain from these countries. In addition to higher wages, they include opportunities for professional advancement and training, better future for family members (such as educational opportunities for children), and better living and working conditions (World Bank, 2019).

The three key problems plaguing the region continue to be unemployment (60\%), the overall economic situation (47\%) and corruption (26\%). Unemployment is listed as a primary concern by a majority of respondents across four of the six economies. Serbia and the Republic of N. Macedonia are the two exceptions where the general economic situation creates the most anxiety within the population surveyed (50\% and 55\%, respectively). Respondents in Kosovo* tend to highlight unemployment to an extent far above the regional average, with some $74 \%$ flagging this issue as the most problematic. At the same time, Serbia and the Republic of N. Macedonia note the fewest concerns in this regard, out of the six surveyed economies (49\% and 51\%). Concerns over the economy and employment are the two top ranked issues across all six economies although corruption comes in at a very close third in Kosovo* (37\% versus 38\% for the overall economic situation). Corruption is also the third most commonly cited problem across the SEE region with crime and brain drain as the other two problems flagged more frequently (17\% and $13 \%$, respectively). Serbia and the Republic of N. Macedonia note an increasing level of anxiety with regards to brain drain (21\% and 16\%). This can, at least in part, be attributed to relatively low salaries across the two economies, driving qualified labour to seek opportunities elsewhere. Bosnia and Herzegovina and the Republic of N. Macedonia are home to most respondents who prioritize political disputes as the source of greatest concern, with $11 \%$ and 12\%, respectively (Balkan Barometer, 2019). 
According to State Statistical Office in report Active Population in the Republic of N. Macedonia Results from the Labour Force Survey, III quarter 2020 the unemployment rate for young from 15-24 is $34.8 \%$ (State Statistical Office, 2020).

\section{KEY FACTORS FOR THE PHENOMENON OF BRAIN DRAIN}

This paper deals with the phenomenon of "brain-drain" as well as the impact of various influencing factors on the deepening of this phenomenon. The aim of this research is to obtain knowledge about the presence of these factors on brain drain by analyzing their effects according to the views of the research sample.

There is a general classification of the factors that cause brain drain to: so-called push and pull factors. Push factors can be identified as political instability, unemployment and uncompetitive remuneration. Pull factor are identified as higher standards of living and working, family reunions and better prospects for children (Meyer, 20004). We can talk about financial factors (salary, employment etc.), but also non-financial factors that include comfort of living, characteristics of the city, climate, natural resources, and other social opportunities (Shane, 2005).

When we talk about the factors that influence the occurrence of migration, in addition to those that encourage this phenomenon (increase in earnings, easier employment, etc.) we should also take into account those factors that significantly influence the decision to emigrate and can largely prevent it. In this sense, we can talk about uncertainty as a factor. The decision to move to another country is followed by the decision to choose a future location. The farther the destination is, the greater the uncertainty, because with the distance many questions remain unanswered and for many things about the future location there is a lack of information. Those who move under uncertainty are likely to return again. This is because a good part of the expectations they had were with a certain amount of risk to be met, such as lower wages than expected, labour market conditions, business relationships, family, friends and so on (Shane, 2005).

Relocation costs are similar to uncertainty. The so-called relocation costs include everything a particular location offers from economic opportunities to quality of life. Of course, this includes the connections that person has in the environment: business network, friends and all those relations that take a long time to build. So, the 
greater the connection of a certain person with the environment, the higher the cost of moving, because in a new location life has to start from scratch. In other words, the future earnings of the new location should be greater than the future earnings of the current location and additionally cover the relocation costs. When all these aspects are covered and financially sustainable then the migration decision can be positive (Shane, 2005).

To deal with this phenomenon, the simplest way is the public policies created by the states. They can greatly affect the prevention of brain drain in many ways, for example policies aimed at improving economic development, reducing unemployment, improving earnings, opening opportunities for self-employment, improving the quality of life by enriching the range of opportunities offered to citizens, etc. In which direction these policies will be directed depends on what are the main reasons that cause this phenomenon. It is a very common practice for public policy to focus on students as a separate population by providing scholarships, grants and opening up opportunities for further education. In fact, governments around the world are trying to keep this group of citizens longer in a particular area / region. Practice shows that the longer you stay in one place, the more life events (marriage, children, own business, etc.) follow, the individuals connect more deeply with the environment and thus increase the cost of moving. This makes the decision to leave the place more difficult (Shane, 2005).

\subsection{CAN ENTREPRENEURSHIP PREVENT BRAIN DRAIN?}

Entrepreneurship is known to be the biggest driver of self-employment and generally reduces unemployment. We have seen that a good part of the reasons for brain drain are the financial factors on which entrepreneurship as a phenomenon can have an impact. That's why we can link entrepreneurship to brain drain. For example, wages/earnings on the one hand are one of the most commonly identified reasons for migration, and on the other hand is a characteristic and motivation of entrepreneurs. Many entrepreneurs start their own business in order to maximize earnings by introducing innovations (Petkovska, 2008). When we talk about wages as a migration factor, it should be noted that people migrate to places where greater potential for its maximization is. It should be noted that when we talk about the salary, as a financial factor, it does not only refers to the monthly income but it should also cover the cost of living, because they will affect the real salary. Apart of the financial factor (amount of 
salary), the decision for migration also takes into account the availability of jobs. Thus, it can be considered that the continuous improvement of the entrepreneurial climate in the society, in the long run can lead to a decrease in the brain drain and retention of educated and talented people in the country (Petkovska, 2008). Apart from the fact that the possibility of self-employment has a positive effect on the prevention of brain drain, when considering entrepreneurship in this context, other aspects typical for entrepreneurship should be taken into account. For example, it should be known that entrepreneurs are active in the regions where they have significant social connections. Business relations and contacts with people are very important for every business, and they are built and are more pronounced in the places where we stay longer and create certain experience. In this sense, knowing the potential investors for entrepreneurs is crucial, but to have such information they need to know the region (Petkovska, 2008). All these aspects can influence the decision to emigrate by increasing the cost of migration.

Apart from the financial factors, entrepreneurship also has its share in the creation of non-financial factors that affect migration. Thus, depending of the type of the business and services offered, entrepreneurship contributes to increasing of the diversity of social, cultural life, its comfort and opportunities for personal development.

\section{RESEARCH METHODS AND RESULTS}

Quantitative research was done by conducting a survey questionnaire through the electronic service for collecting and analyzing research data - Google Forms. The graphical representation is presented through the MS Excel program. The research included 224 respondents, of which $70 \%$ were women and $30 \%$ men. Most of the respondents are able-bodied population that is directly affected by the reasons for emigration. Most of them are also people aged 31-64 years (79\%), and 19\% young people up to 30 years. Only $2 \%$ were retirees who are indirectly affected by this phenomenon. 


\section{Graph 1 - Gender of the respondents}



Source: Own research


Source: Own research

Respondents had the opportunity to either choose one of the offered answers (Completely agree, partially agree, Agree, Disagree and completely disagree), or rank them by importance from 1 to 5 (1 highest impact - 5 lowest impact).

The research consisted of the following statements, which the respondents had to assess:

Graph 3 - Employment immediately after graduation affects the phenomenon of brain drain



Source: Own research

The claim Employment immediately after graduation affects the phenomenon of brain drain was recognized as correct by the respondents, but there was different thinking about the extent to which it is an important cause of brain drain. Thus, the highest percentage of respondents (35\%) answered that they partially agree with this statement, 29\% fully agree, and 25\% agree that employment immediately after graduation affects the phenomenon of brain drain. 
Graph 4 - Phenomenon of "employment based on political ties" affects the phenomenon of brain drain

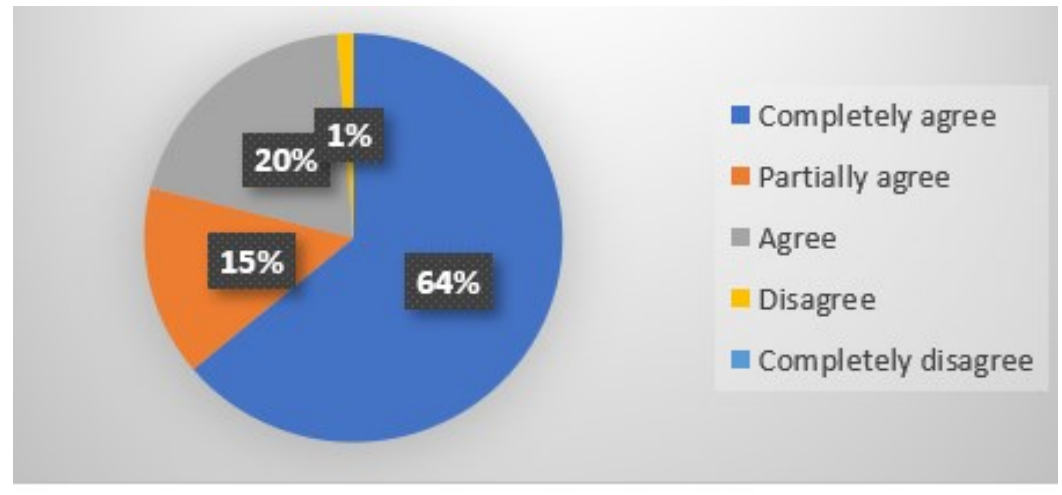

Source: Own research

Contrary to the previous claim, the phenomenon of "employment based on political ties " affects the phenomenon of brain drain is highly recognized by examinations as the main cause of brain drain with as much as $64 \%$ of responses.

\section{Graph 5 - Disproportion between available labor force and labor market affects phenomenon of brain drain}

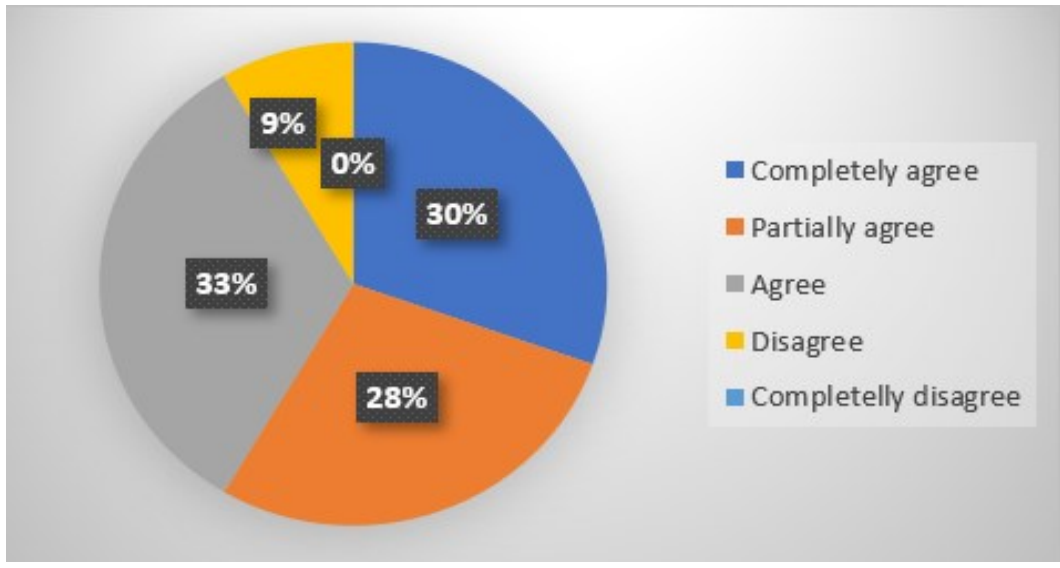

Source: Own research

The condition on the labor market was also considered as a factor that may contribute to the brain drain from the country. Thus, the disproportion that exists between the qualified staff and the demand on the labor market was taken into account and included in the research, but the respondents had a divided opinion with a narrow difference in the answers about how this condition is crucial for the brain drain. 


\section{Graph 6 - Discrimination in employment affects phenomenon of brain drain}

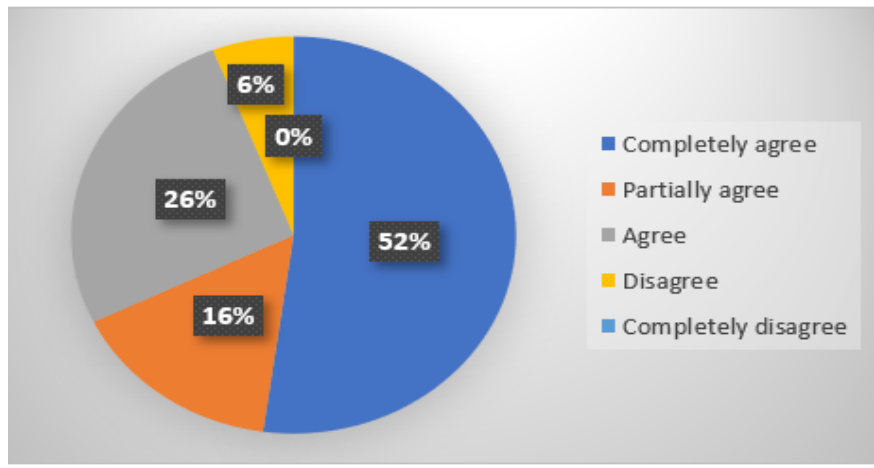

Source: Own research

Graph 7 - Unstable jobs and a salary that doesn't match the competencies affects the phenomenon of brain drain

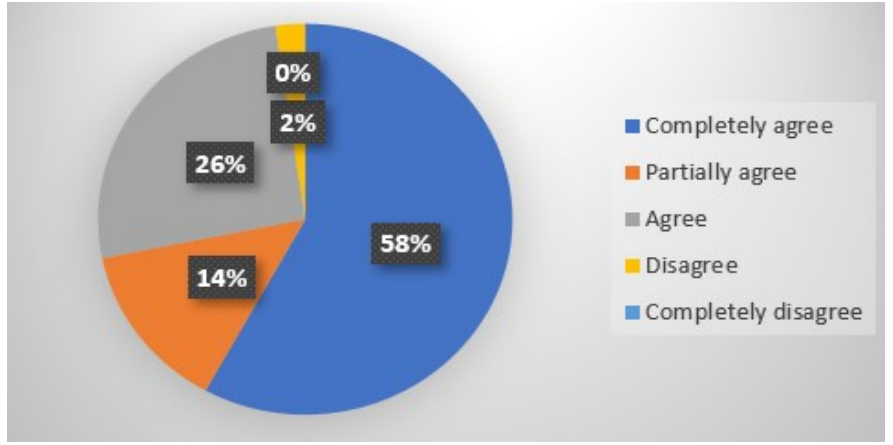

Source: Own research

Graph 8 - Unprotected and unguaranteed labor rights, especially when it comes to young people, affects the phenomenon of brain drain



Source: Own research

It is significant that unstable jobs and wages that do not match the competencies (58\%), discrimination in employment on various grounds (52\%) and unprotected labor rights (52\%) are highly recognized as key reasons for demotivation of the citizens who seek its realization abroad. 
Graph 9 - Further education, additional training and retraining affects the phenomenon of brain drain

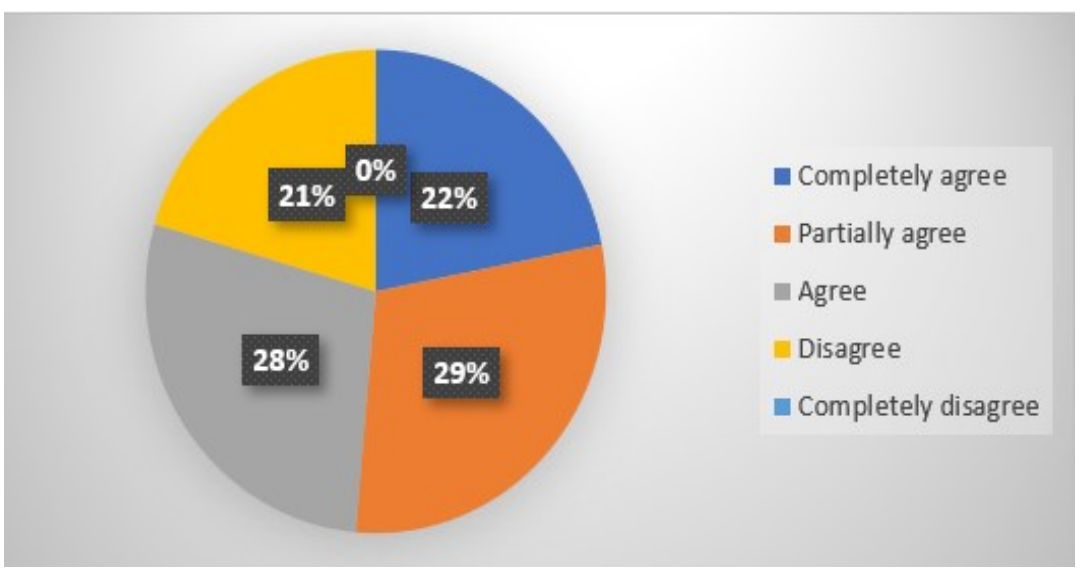

Source: Own research

There is a diversity in opinion how great is a need for further education and retraining of the labor force in order to bridge the gap between supply and demand in the labor market and stop the brain drain. 28\% agree, and 29\% partially agree with the possibility that this is the cause of the brain drain, while a relatively low $22 \%$ fully believe that this may be the cause of migration.

\section{Graph 10 - Deep politicization in society affects the phenomenon of brain drain}

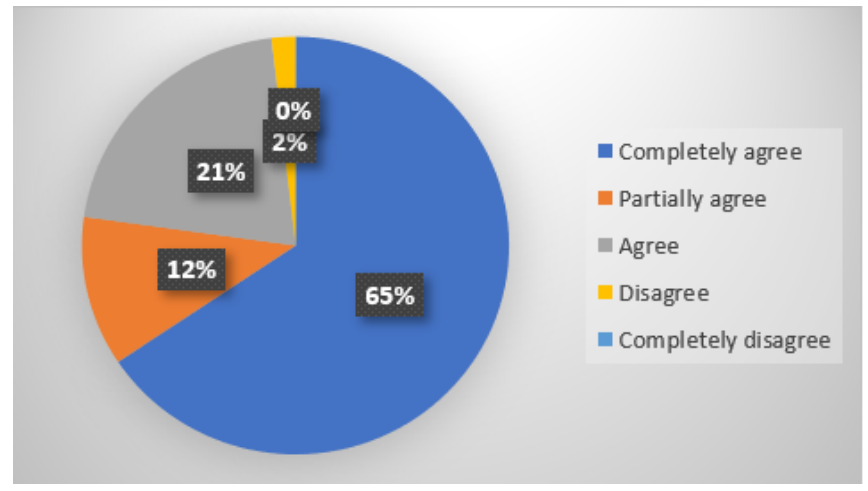

Source: Own research

From the answers of the respondents it can be seen that as a key problem that needs to be solved quickly is the deep politicization in the society, which even $66 \%$ of the respondents said that it is problematic and alarming. 
Graph 11 - Having your own business with solid earnings affects the

phenomenon of brain drain

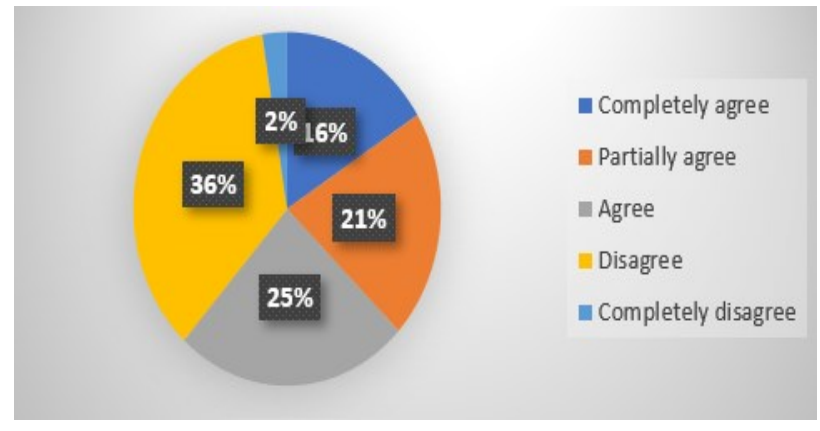

Source: Own research

Graph 12 - Access to financial resources from the state for starting your own business affects the phenomenon of brain drain

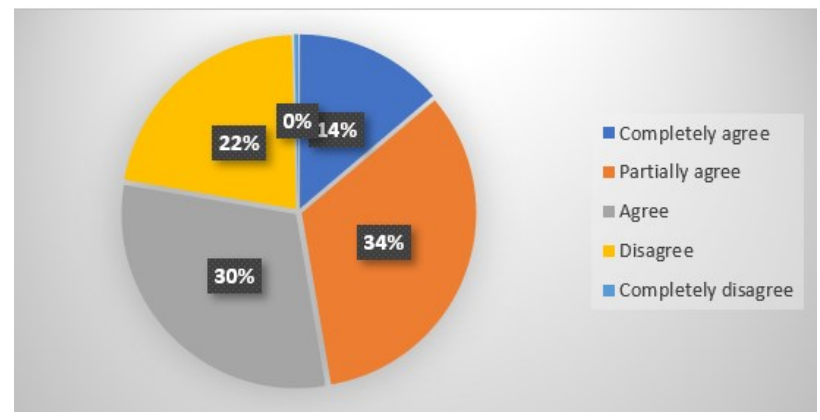

Source: Own research

Graph 13 - Bureaucracy and complex administrative procedures affects the phenomenon of brain drain



Source: Own research

Economic issues directly related to the development of entrepreneurship such as access to finance for establishing businesses, difficult bureaucratic procedures, opportunities for self-employment and solid earnings are recognized as important, but 
are not detected as a high priority in terms of emigration and outflow of educated talented people. In contrast, trust in the legal system is set high on the priority scale for solving as a problem by $53 \%$ of respondents.

\section{Graph 14 - Trust in the legal system affects the phenomenon of brain drain}

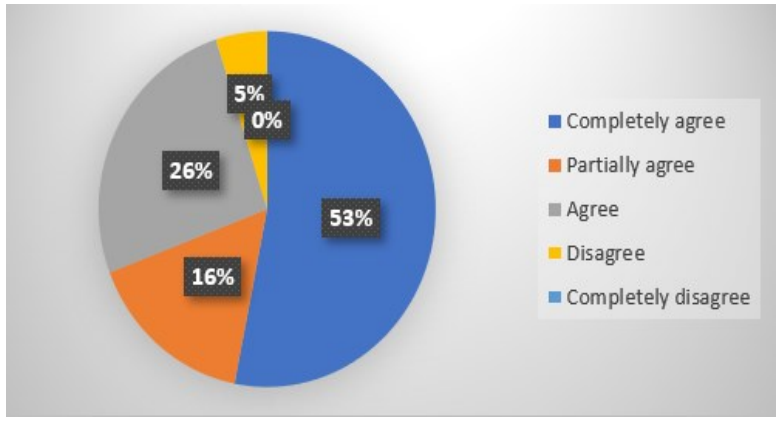

Source: Own research

The second part of the questionnaire consists of 5 factors: quality of life, work and work environment, Family security, political stability and poverty which of the respondents should be rated on a scale of 1 to 5 ( 1 highest importance, 5 lowest importance).

\section{Graph 15 - Quality of life}

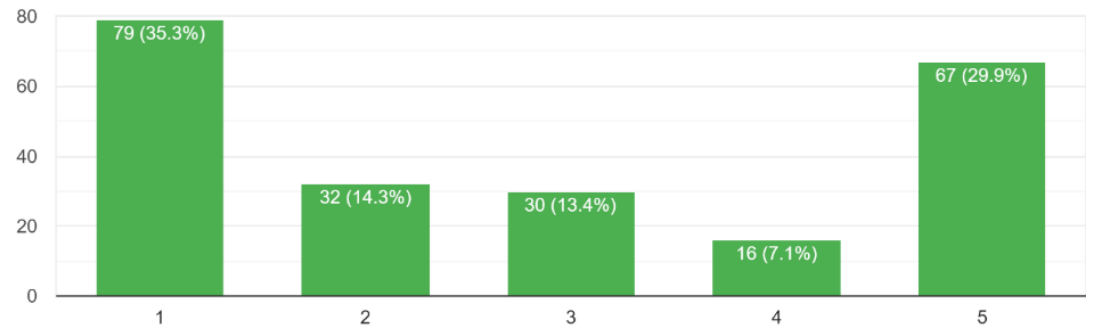

Source: Own research

Graph 16 - Work and work environment



Source: Own research 


\section{Graph 17 - Family safety}

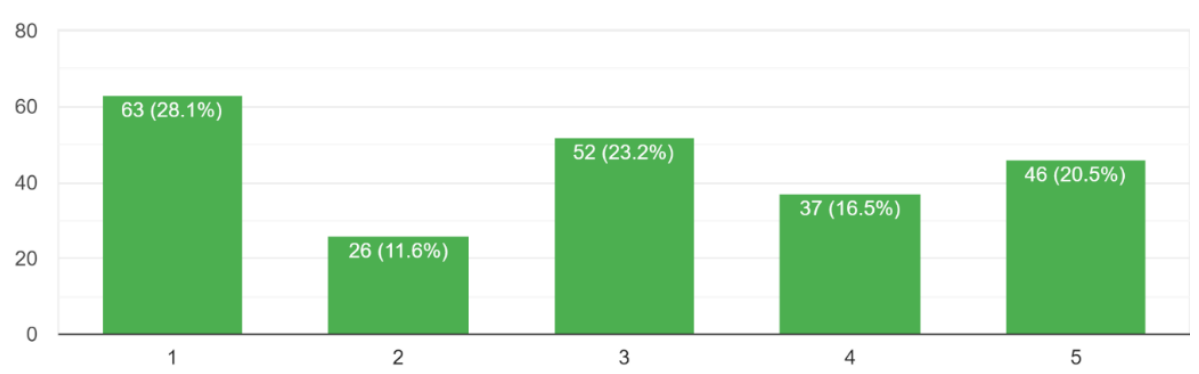

Source: Own research

\section{Graph 18 - Political stability}

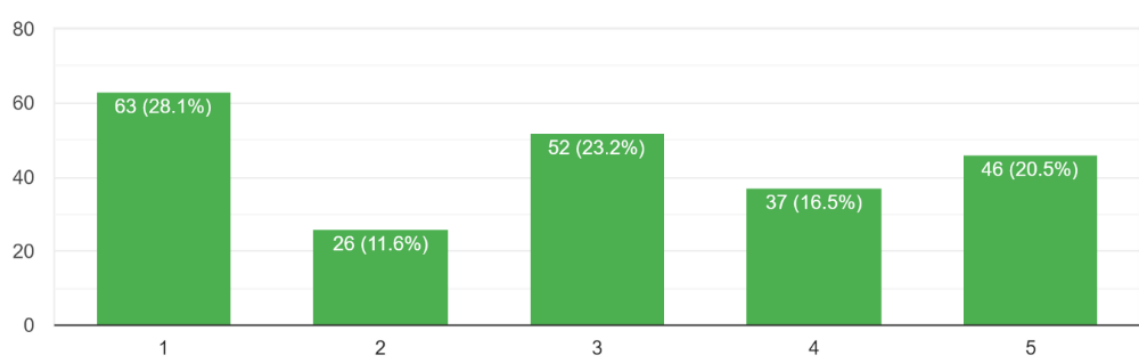

Source: Own research

\section{Graph 19 - Poverty}

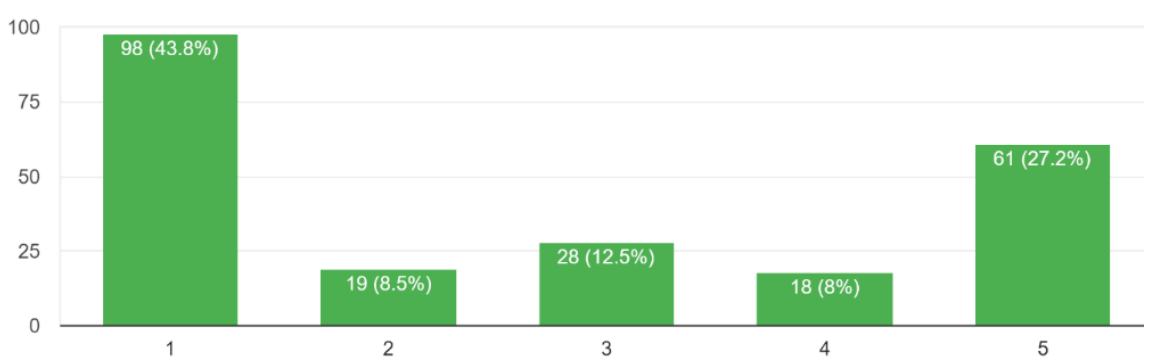

Source: Own research

From the answers of the respondents, it can be seen that there is a diversity in the opinions about some of the offered factors, but the greatest value has poverty as a factor, which in $43.8 \%$ of the respondents is considered the main reason for emigration. 


\section{CONCLUSION}

Raising awareness about the 'brain drain' and the need for timely solutions is crucial for the region's future prosperity. There is an urgency to apply direct specific policies to soften immigration and its effects on society.

When we talk about brain drain, it is good to know that this phenomenon distinguishes two concepts: brain exchange and brain waste. (Feld, 2021). From the results of this research it cannot be concluded whether in the Republic of N. Macedonia it is a matter of brain exchange or brain waste. It was not a subject of the research at all and for that purpose additional research will be needed. That is why we use the general term brain drain, which has been defined as the departure of educated and professional people from one country, economic sector, or field for another usually for better pay or living conditions.

From conducted research it can be concluded that financial factors are not recognised as a key reason for emigration from Republic of N. Macedonia. Namely, if we analyze the independent variables with financial/economic sign that are included in the research, such as: employment, owning a business, earnings, access of the financial resources for starting a business, etc. we can concluded that by the respondents they are recognised as important on this issue, but are not considered key and crucial to the general state of brain drain. The frequency of the respondent's answers shows extremely high values in the factors: employment based on political ties $64 \%$, politicization of the society $65 \%$, and trust in legal system $53 \%$. In the ranking by importance as causes of brain drain: quality of life, work and work environment, family security, political stability and poverty as factors, poverty is unequivocally most recognized as one of the most motivating reasons for people to leave N. Macedonia. Looking at the general context, it should be mentioned that political stability, given that the last decade has been significantly disrupted in $\mathrm{N}$. Macedonia, is one of the recognized factors for emigration. The scientific literature says that political instability manifested as political changes can be beneficial to entrepreneurship in the short term.

Political changes may contribute to increased business start-ups, but they are detrimental to the long-term survival of enterprises. Therefore, they do not guarantee good entrepreneurial performance (Shane, 2003). This aspect of the political changes, together with the rest of the factors such as stability and trust in the legal system, 
corruption and politicization, which in this case are manifested as discrimination in employment and remuneration for employment, quality of life, etc. in the scientific literature are considered as the main brake on entrepreneurship (Serafimovska, 2014). Thus, it can be concluded that development of the entrepreneurship through government measures aimed at increasing access to financial resources and the other programs that can facilitate the establishment and operation of the enterprises, will not directly contribute to preventing the brain drain. On the contrary, it can be concluded that development of entrepreneurship and the brain drain have common causes (of stagnation, i.e. increased outflow). They need to be removed through appropriate government policies and reforms aimed mainly at eliminating politicization and corruption. Poverty is one of the highest ranking causes of outflow, but the overall results of the research show that it can be overcome not by typical financial measures, but by changing the general climate in society and creating better social living conditions through reduced politicization, corruption and different types of discrimination.

Young people are the social and economic force of a country, representing its potential for the future. In a time of constantly developing technologies and rapidly changing political, social and economic realities they are among the most equipped to contribute to the solutions of the future. The SEE region should focus on giving young people reasons to stay by providing better jobs, more opportunities and a higher standard of living. To get a more accurate picture of the situation in the country, future research could be expanded to determine the extent of brain waste, which implies a skill loss that occurs when highly skilled workers migrate into forms of employment not requiring the application of skills and experience applied in the previous job.

\section{REFERENCES}

- Anderson, T. Curley, M.G., Formica, P., (2010). Entrepreneurship: The Key to social and Economic Transformation, Springer, pp. 180.

- Feld, S., (2021). International Migration, Remittances and Brain drain: Impacts on Development, Springer, pp. 25-28..

- INSEAD, (2019). The Global Talent Competitiveness Index 2019: Global Talent in the Age of Artificial Intelligence, Fontainebleau: France.

- INSEAD, (2020). The Global Talent Competitiveness Index 2020: Global Talent in the Age of Artificial Intelligence, Fontainebleau: France.

- Meyer, S., (2004). The Brain Drain problem: The case of India, GRIN Verlag, pp. 2.

- Panagiotakopoulos, A. (2020). Investigating the factors affecting brain drain in Greece: Looking beyond the obvious. World Journal of Entrepreneurship, Management and Sustainable Development, 16(3), pp.207- 218. 
- Petkovska, B.T, (2008). "Innovation - important factor for improving the Competitiveness of Small and Medium Sized Enterprises"; in Entrepreneurship innovation and competitiveness, Skopje: Economic Institute. pp. 22.

- Schwab, K. (2017). The Global Competitiveness Report 2017-2018. World Economic Forum: Geneva. accessed on 1 december 2020. http://www3.weforum.org/docs/GCR20172018/05FullReport/TheGlobalCompetitivenessReport2017\%E2\%80\%932018.pdf.

- Ramhorst, A., (2021). Study on Youth Employment in the Western Balkan. Sarajevo: Regional Cooperation Council.

- Serafimovska, H., Sotiroski., Lj. (2014), "Implications of the Legal Framework for the Development of Entrepreneurship", International Review of Social Sciences and Humanities Vol. 7, No. 1, pp. 263-273.

- Shane, S, (2003). A General Theory of Entrepreneurship: The Individual-Opportunity Nexus, Edward Elgar, Massacusets, pp. 23.

- Shane, S., (2005). Economic Development Through Entrepreneurship: Government, University and Business Linkages", Edward Elgar Publishing, Inc., Massachusetts, pp. 108-110.

- State Statistical Office, (2020) . Active Population in the Republic of North Macedonia Results from the Labour Force Survey, III quarter 2020, accessed on 7 december 2020. http://www.stat.gov.mk/pdf/2020/2.1.20.34 mk.pdf.

- World Bank. (2019). Europe and Central Asia Economic Update, Fall 2019 : Migration and Brain Drain. Washington, DC: World Bank. accessed on 5 december 2020. https://openknowledge.worldbank.org/handle/10986/32481. 